\title{
STRATEGI LAYANAN BIMBINGAN DAN KONSELING DALAM MENGUATKAN KESADARAN DISABILITAS DI SEKOLAH INKLUSI
}

\author{
Bagus Rachmad Saputra \\ Manajemen Pendidikan, Fakultas Ilmu Pendidikan, Universitas Negeri Malang \\ bagusrachmad47@gmail.com \\ Muhammad Hasbi Al Haikal, Nur Hidayah \\ Bimbingan dan Konseling, Fakultas Ilmu Pendidikan, Universitas Negeri Malang \\ hasbialhaikalbkfipum@gmail.com \\ Riza Ilmana Harir \\ Pendidikan Luar Biasa, Fakultas Ilmu Pendidikan, Universitas Negeri Malang \\ ilmanaharir@gmail.com
}

\begin{abstract}
Abstrak
Penelitian ini bertujuan untuk (1) mengembangkan strategi yang tepat dalam memberikan layanan bimbingan dan konseling di sekolah inklusi dan (2) penguatan kesadaran disabilitas bagi guru bimbingan dan konseling dalam memberikan layanan di sekolah inklusi. Pendekatan dalam penelitian ini adalah menggunakan metode penelitian kualitatif. Dimana peneliti melakukan pengumpulan data dengan terjun langsung ke lokasi penelitian. Berdasarkan kecukupan informasi yang diperoleh oleh peneliti, penelitian ini memilih SMK 13 Kota Malang. metode yang dilakukan dengan model studi kasus. Peneliti berfokus pada layanan bimbingan dan konseling dengan menggali secara dalam dari kasus yang ada di lokasi penelitian. Studi dilakukan dengan mencari sumber literatur yang relevan kemudian dibandingkan dengan literatur lain yang kemudian ditarik menjadi sebuah kesimpulan atau pemahaman terkait dengan tema yang ditulis. Hasil yang diharapkan dalam penulisan artikel ini adalah (1) strategi layanan bimbingan dan konseling yang dirasa tepat untuk diimplementasikan di sekolah inklusi dan (2) perlunya penguatan kesadaran disabilitas bagi guru bimbingan dan konseling di sekolah inklusi.
\end{abstract}

Kata Kunci: strategi, layanan, bimbingan dan konseling, kesadaran disabilitas

\begin{abstract}
This study aims to (1) develop appropriate strategies in providing guidance and counseling services in inclusive schools and (2) strengthening disability awareness for guidance and counseling teachers in providing services in inclusive schools. The approach in this research is to use qualitative research methods. Where researchers conducted data collection by jumping directly into the study site. Based on the adequacy of information obtained by researchers, this study chose SMK 13 Malang. the method used is the case study model. Researchers focus on guidance and counseling services by digging deeply from cases in the study location. The study was conducted by finding relevant sources of literature and then compared with other literature which was then drawn into a conclusion or understanding related to the theme written. The expected results in writing this article are (1) guidance and counseling service strategies that are deemed appropriate for implementation in inclusive schools and (2) the need to strengthen disability awareness for guidance and counseling teachers in inclusive schools.
\end{abstract}

Keywords: strategy, service, guidance and counseling, disability awareness

\section{PENDAHULUAN}

Negara Indonesia menjamin setiap warga negaranya dalam mendapatkan pendidikan yang adil dan merata. Sebagaimana telah diatur dalam Undang-undang Sistem Pendidikan Nasional No. 23 Tahun 2003 Pasal 3, "Pendidikan diselenggarakan secara demokratis dan berkeadilan serta tidak diskriminatif dengan menjunjung tinggi hak asasi manusia, nilai keagamaan, nilai kultural, dan kemajemukan bangsa". Artinya negara Indonesia secara langsung telah menjamin upaya pemenuhan pendidikan yang adil dalam setiap satuan pendidikan untuk seluruh warga negaranya melalui undang-undang tersebut. Kemajemukan masyarakat yang dimiliki oleh Indonesia begitu beragam, mulai dari keberagaman suku, budaya, bahasa hingga kebudayaan khas yang menjadi kekayaan tersendiri bagi bangsa Indonesia. Berangkat dari kemajemukan tersebut, warga negara Indonesia yang beranekaragam ini harus mendapat jaminan pendidikan sebagaimana telah diatur dalam undang-undang. Terlepas dari keberagaman warga yang ada, ada hal yang perlu diperhatikan pula keberadaannya. Masyarakat kaum minoritas, seperti penyandang disabilitas atau yang memiliki kebutuhan khusus untuk mendapatkan pendidikan yang sesuai dengan kebutuhanya yang 
acapkali justru mendapatkan diskriminasi. Seperti tidak adanya lembaga pendidikan formal yang aksesibel terhadap kaum disabilitas.

Penyandang Disabilitas adalah setiap orang yang mengalami keterbatasan fisik, intelektual, mental, sensorik dalam jangka waktu lama yang dalam berinteraksi dengan lingkungan dapat mengalami hambatan dan kesulitan untuk berpartisipasi secara penuh dan efektif dengan warga negara lainnya berdasarkan kesamaan hak. Dimana keberadaan penyandang disabilitas adalah salah satu komponen minoritas masyarakat yang dijamin untuk mendapatkan layanan pendidikan yang sesuai oleh undang-undang. Sebagaimana disebutkan oleh UndangUndang No. 8 tahun 2016 Pasal 5 menyebutkan secara jelas salah satu hak yang wajib dipenuhi kepada penyandang disabilitas adalah layanan pendidikan.

Bentuk layanan pendidikan khusus yang dapat diselenggarakan oleh satuan pendidikan memiliki tiga model. Model yang pertama adalah layanan pendidikan khusus segregasi. Layanan pendidikan tersebut dilaksanakan, dengan memberikan pendidikan secara eksklusif bagi peserta didik berkebutuhan khusus dalam satuan pendidikan atau sekolah. Model yang kedua adalah pendidikan integrasi. Layanan pendidikan integrasi dilaksnakan dengan menyediakan kelas khusus bagi peserta didik berkebutuhan khusus di sekolah regular. Model yang terakhir adalah layanan pendidikan inklusi. Layanan pendidikan inklusi adalah layanan yang memberikan pendidikan kepada peserta didik berkebutuhan khusus dengan menggabungkan peserta didik tersebut dalam satu rombogan belajar dengan peserta didik regular sehingga diperlukan strategi yang tepat dalam memberikan layanan terhadap peserta didik berkebutuhan khusus terutama di sekolah inklusi.

Dikaitkan dengan layanan pendidikan bukan hanya sekedar layanan pembelajaran namun juga layanan bimbingan dan konseling di sekolah. Layanan bimbingan dan koseling adalah layanan yang memandirikan, dalam upaya perkembangan peserta didik secara optimal. Sementara tuntutan konselor di sekolah yakni hendaknya mampu mengembangkan 4 komponen layanan secara maksimal. Layanan tersebut meliputu layanan dasar, responsive, perencanaan individu, dan dukungan sistem pembelajaran. Komponen dukungan sistem dalam layanan bimbingan dan konseling tidak terbatas pada pemenuhan kebutuhan materi dari sistem formal yang ada, namun lebih dari itu konselor hendaknya mampu mengembangkan dukungan sistem dalam upaya memberikan lingkungan social yang baik kepada semua peserta didik di sekolah termasuk peserta didik berkebutuhan khusus.

Komponen dukngan sistem tersebut telah diatur sebagaimana disebutkan dalam lampiran Permendikbud No. 111 tahun 2014 adalah layanan dalam bentuk: (a) Konsultasi; (b) Program kerjasama dalam menciptakan lingkungan kondusif bagi konseli; (c) berpartisipasi aktif dalam perencanaan program sekolah; (d) melakukan penelitian dan pengembangan profesi yang berkelanjutan. Dimana konselor memiliki wewenang dalam merencanakan program layanan dengan berkolaborasi bersama pihak terkait guna mengembangkan kesadaran disabilitas dalam sekolah inklusi. Selain itu konselor juga dapat membangun kerjasama dengan pihak luar seperti lembaga pemerintah lain dalam mengembangkan suatu program. Perlu disadari bersama bahwa konselor di sekolah inklusi perlu dan wajib dalam mengembangkan strategi layanan bimbingan dan konseling yang tepat untuk memberikan akses pendidikan yang sesuai pada peserta didik berkebutuhan khusus. Hal tersebut dilakukan untuk memberikan lingkungan pendidikan yang aksesibel bagi warga berkebutuhan khusus yang ada di sekolah inklusi.

\section{METODE}

Pendekatan dalam penelitian ini adalah menggunakan metode penelitian kualitatif. Dimana peneliti melakukan pengumpulan data dengan terjun langsung ke lokasi penelitian. Berdasarkan kecukupan informasi yang diperoleh oleh peneliti, penelitian ini memilih SMK 13 Kota Malang. metode yang dilakukan dengan model studi kasus. Peneliti berfokus pada layanan bimbingan dan konseling dengan menggali secara dalam dari kasus yang ada di lokasi penelitian.

Sementara data diperoleh peneliti melalui teknik wawancara mendalam, pengamatan berperan serta, dan studi dokumentasi (Ulfatin, 2015). Informasi awal diperoleh melalui wawancara dengan kepala sekolah selaku informan kunci, konselor, dan guru. Kemudian pengumpulan data dilanjutkan dengan melakukan pengamatan berperan serta dengan mengamati aktivitas layanan bimbingan dan konseling di SMK 13 Kota Malang. selanjutnya peneliti melakukan studi dokumentasi untuk mengecek dokumen-dokumen pendukung yang berkaitan dengan layanan bimbingan dan konseling di sekolah inklusi. Data yang diperoleh selanjutnya disajikan dalam bentuk catatan lapangan dan kemudia direduksi untuk diperoleh data yang sesuai dengan fokus penelitian (Ulfatin, 2015). Kemudian data diuji validitasnya dengan menggunakan teknik trianggulasi yakni trianggulasi teknik dan informan. Selanjutnya data disajikan dalam bentuk artikel ilmiah.

\section{HASIL DAN PEMBAHASAN}

Penyandang disabilitas adalah salah satu komponen minoritas masyarakat yang dijamin untuk mendapatkan pendidikan yang sesuai oleh undang-undang. Sebagaimana disebutkan oleh Undang-Undang No. 8 Tahun 2016 Pasal 5 menyebutkan secara jelas bahwa salah satu hak yang wajib dipenuhi kepada penyandang disabilitas adalah pendidikan. Artinya kewajiban bangsa ini kepada penyandang disabilitas adalah persamaan hak dalam menempuh pendidikan yang layak.

Pendidikan inklusi yang diselenggarakan memiliki patokan hokum berupa Undang-Undang No. 70 Tahun 2009 yang menyebutkan bahwa pendidikan inklusif adalah sistem penyelenggaraan pendidikan yang memberikan kesempatan kepada semua peserta didik yang memiliki kelainan dan memiliki potensi kecerdasan dan/atau bakat istimewa untuk mengikuti pendidikan atau pembelajaran dalam satu lingkungan pendidikan secara bersama-sama dengan peserta didik pada umumnya. 
Perkembangan pendidikan inklusi di Indonesia dari tahun-ketahun selalu mengalami penyesuaian. Pendidikan inklusi merupakan sebuah terobosan baru dalam dunia pendidikan di Indonesia berkenaan dengan penyelenggaraan pendidikan untuk semua. Ditengah masyarakat dan praktek pendidikan inklusi sendiri mengalami banyak tantangan mulai dari hambatan sampai dengan penolakan. Kesalahpahaman pelaksanaan pendidikan inklusi pun masih sering ditemui dalam proses implementasinya di sekolah. Perlu adanya penjelasan yang jelas dan menyeluruh untuk merubah cara pandang berbagai kalangan terkait pendidikan inklusi. Berkenaan dengan hal tersebut, pada dasarnya pendidikan inklusi mengajak semua warga yang bersinggungan pada pendidikan baik di sekolah maupun di luar sekolah untuk terlibat dalam aktivitas mengembangkan pola pendidikan yang baik untuk memenuhi kebutuhan peserta didiknya termasuk peserta didik dengan kebutuhan khusus. Keterampilan dasar yang diperlukan oleh tenaga kependidikan di sekolah yang menyelenggarakan pendidikan inklusi adalah ketrampilan menyampaikan materi maupun memberikan layanan pendidikan untuk peserta didik berkebutuhan khusus.

Pada dasarnya pemenuhan kebutuhan yang ada untuk peserta didik berkebutuhan khusus di sekolah inklusi tidak hanya berkenaan dengan proses pendidikan didalam kelas beserta kurikulum dan proses pengajaranya, namun peserta didik berhak pula untuk berinteraksi dengan baik bersama-sama dengan peserta didik lain disekitarnya, berinteraksi dengan baik bersama seluruh tenaga pendidikan dan warga sekolah, bahkan berinteraksi dengan baik pula terhadap sekitar lingkungan sekolah.

Interaksi yang terbangun dengan baik akan memberikan motivasi yang baik kepada peserta didik berkebutuhan khusus dalam mengembangkan bakat dan minatnya. Lingkungan yang ada disekitar sangat berpengaruh dalam pembentukan pola pikir dan karakter peserta didik yang ada, terutama peserta didik berkebutuhan khusus Penyandang disabilitas sebagaimana disebutkan dalam undang-undang No 70 tahun 2009 adalah seorang yang memiliki hambatan-hambatan sebagaimana berikut: (a) tunanetra; (b) tunarungu; (c) tunawicara; (d) tunagrahita; (e) tunadaksa; (f) tunalaras; (g) berkesulitan belajar; (h) lamban belajar; (i) autis; (j) memiliki gangguan motorik; (k) menjadi korban penyalahgunaan narkoba, obat terlarang, dan zat adiktif lainnya; (1) memiliki kelainan lainnya; (m) tunaganda.

Sementara hak-hak yang perlu dipenuhi dalam proses pendidikan sendiri sebagaimana disebutkan dalam peraturan No 8 Tahun 2016 adalah (a) mendapatkan pendidikan yang bermutu pada satuan pendidikan di semua jenis, jalur, dan jenjang pendidikan secara inklusif dan khusus; (b) mempunyai Kesamaan Kesempatan untuk menjadi pendidik atau tenaga kependidikan pada satuan pendidikan di semua jenis, jalur, dan jenjang pendidikan; (c) mempunyai Kesamaan Kesempatan sebagai penyelenggara pendidikan yang bermutu pada satuan pendidikan di semua jenis, jalur, dan jenjang pendidikan; dan (d) mendapatkan Akomodasi yang layak sebagai peserta didik seperti pada umumnya.
Dalam pemenuhan hak tersebut, peserta didik di sekolah inklusi berhak mendapatkan akses yang sesuai dengan kebutuhanya, baik akses fisik maupun akses sosial. Dimana akses yang ada memberikan proses belajar bagi peserta didik berkebutuhan khusus di sekolah inklusi. Ditinjau dari aspek fisik seperti fasilitas gedung, perpustakaan, pusat peribadahan dan lain sebagainya sangat berpengaruh dalam proses pendidikan seorang peserta didik. Sedangkan aspek sosial, peserta didik berhak mendapatkan kenyamanan belajar dalam proses di sekolah guna mendapatkan kemantapan psikologis proses pendidikan. Peserta didik dengan hambatan khusus sering mengalami keterbatasan dalam mengakses lingkungan sosial yang seringkali justru menolak keberadaan mereka.

Layanan bimbingan dan konseling untuk sekolah dilaksnakan dengan model layanan Bimbingan dan konseling perkembangan secara komperhensif. Strategi layanan ini diberikan dengan tujuan kemandirian peserta didik dan perkembangan optimal peserta didik. Dalam aktivitas penyusunan layanan ini konselor sekolah memegang beberapa prinsip layanan yang diselenggarakan. Layanan konseling yang dilakukan akan efektif ketikakonselor mampu melakukan kolaborasi dengan sekolah, orang tua, pendidik dan pihak lain dalam membangun iklim belajar yang akomodatif guna mencapai tujuan bimbingan dan konseling.

Ada beberapa hal yang perlu diperhatikan dalam menjalankan layanan bimbingan dan konseling perkembangan sesuai dengan pendapat Bowers \& Hatch (Fathur Rahman, 2002). Pertama, bersifat pengembangan, hal ini berarti layanan bimbingan dan konseling hendaknya mengembangkan aspek perkebangan peserta didik, mulai dari pribadi, sosial, belajar dan karir. Kedua bersifat preventif, layanan yang bersifat preventif ini berarti layanan bimbingan dan konseling yang dilaksnakan hendaknya dapat mengantisipasi sejak dini perilaku malasuai dari pribadi konseli. Membangun program BK yang ada dalam mmenuhi kebutuhan peserta didik sebagaimana sifat layanan yakni prefentif dan pengembangan dengan mengacau kebutuhan peserta didik yang ada, membawa konselor di sekolah untuk memnuhi langkah dalam perencanaan program yang ada sehingga layanan yang diberikan dapat sesuai dengan kebutuhan konseli. Adapun layanan bimbingan dan konseling di sekolah sebagaimana berikut ini, komprehensif adalah perencanaan (planning), pengorganisasian (organizing), penerapan (implementating), dan evaluasi (evaluation) Schmidt (2008).

Implementasi program bimbingan dan konseling perlu didukung oleh ketersediaan sumber daya manusia yang terampil. Guru bimbingan dan konselinng atau konselor diharapkan memahami seperangkat pengetahuan dan keterampilan yang mendukung implementasi program bimbingan dan konseling di sekolah inklusi. Pengetahuan yang utuh tentang teori perkembangan. Keterampilan yang dimiliki konselor adalah melakukan koordinasi dengan berbagai pihak dalam melaksanakan program bimbingan dan konseling. Selanjutnya konselor memiliki kepemimpinan yang kokoh dalam menjalankan program bimbingan. Menurut ASCA (2012) memberikan rekemondasikan bahwa konselor sekolah mengalokasikan 
waktu layanan minimal $80 \%$ atau lebih pada komponen layanan direktif yakni layanan dasar, layanan responsif, dan layanan perencanaan individual yang diberikan pada peserta didik. Sedangkan sisa waktu pembelajaran sekitar $20 \%$ untuk aktivitas manajemen program dan dukungan sistem. Selanjutnya konselor dapat mengalokasikan $20 \%$ waktunya dalam membangun lingkungan yang kondusif bagi konseli untuk keberlangsungan perkembanganya.

Penyelenggaraan layanan bimbingan dan konseling di sekolah inklusi, dimana layanan bimbingan dan konseling harus terlibat aktif dalam setiap kegiatan perencanaan pembelajaran bagi peserta didik. Sebagaimana disebutkan oleh (Salvia dkk, 2010), Childs study teams are composed of parents, teachers, and other specialist that may include a schools psychologist, specials educator, speech/languages pathologist, Counselors, nurse, social workers, and principle, together, this individuals identify pre-referrals, intervention strategic to put into place prior to initiating a forma specials education eligibility evaluation. Konselor perlu terlibat aktif dalam dalam penyususunan program pendidikan di sekolah inklusi bagi peserta didik berkebutuhan khusus maupun peserta didik umum. Program bimbingan dan konseling dalam sekolah inklusi tidak hanya fokus pada individu peserta didik berkebutuhan khusus namun juga menyediakan lingkungan yang mnunjang perkembanganya. Hal ini berarti konselor dapat berinovasi dalam layanan baik bersifat langsung maupun tidak langsung untuk menunjang kesadaran disabilitas sekolah dan lingkungan sekolah untuk menciptakan lingkungan sekolah yang aksesibel bagi peserta didik berkebutuhan khusus.

Lingkungan yang aksesibel untuk peserta didik berkebutuhan khusus dapat dilihat dari beberapa aspek. Aspek yang nampak seperti fasilitas gedung, pusat layanan, pusat kegiatan peserta didik, fasilitas public, media pembelajaran dan lain sebagainya. Sedangkan aspek lingkungan social yang menjadi tolak ukur kesadaran disabilitas adalah penerimaan terhadap peserta didik berkebutuhan khusus, pendampingan terhadap peserta didik berkebutuhan khusus, proses pembelajaran dan kurikulum yang digunakan, pelibatan secara aktif peserta didik berkebutuhan khusus dalam setiap agenda sekolah yang dilaksnakan. Berikut Gambar 1 yang menjelaskan sasaran layanan bimbingan dan konseling yang dilaksanakan di sekolah inklusi,

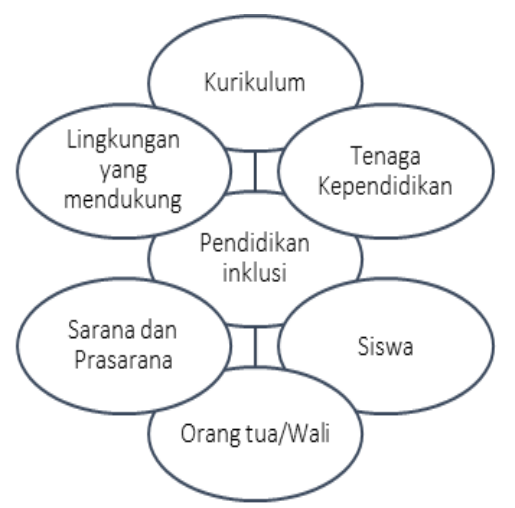

Gambar 1. Bagan Pendidikan Inklusi Disabled People's Associations. 2016
Layanan bimbingan dan konseling di sekolah inklusi berupaya mewujudkan kesadaran disabailitas melalui beberapa program kegiatan. Kegiatan yang dilaksanakan harus memenuhi aspek sebagaimana disebutkan pada gambar 1. Sedangkan fokus layanan pengembangan yang dilaksnakan menyesuaikan dengan kondisi sekolah, hasil analisis kebutuhan dan pertimbangan lainya. Dengan demikian konselor dapat menjalankan tugasnya secara proaktif untuk mewujudkan sekolah yang ramah disabilitas.

Program bimbingan dan konseling yang dilaksanakan di sekolah inklusi dilaksanakan dengan beberapa tahapan. Intervensi layanan bimbingan dan konseling dalam mewujudkan kesadran disabilitas dapat masuk kedalam program bimbingan dan konseling secara umum yang terintegrasi dengan program sekolah. Adapun layanan bimbingan dan konseling untuk meningkatkan kesadaran disabilitas adalah sebagai Tabel 1 berikut ini.

Tabel 1. Layanan Bimbingan Dan Konseling Untuk Meningkatkan Kesadaran Disabilitas

\begin{tabular}{|c|c|c|}
\hline Program & $\begin{array}{l}\text { Tahapan } \\
\text { Program }\end{array}$ & Uraian Kegiatan \\
\hline \multirow[t]{4}{*}{$\begin{array}{l}\text { Peningkatan } \\
\text { Kesadaran } \\
\text { disabilitas } \\
\text { lingkungan } \\
\text { sekolah }\end{array}$} & Perencanaan & $\begin{array}{l}\text { Menghimpun data melalui } \\
\text { asesmen } \\
\text { - Menyusun Program } \\
\text { layanan secara sistematis } \\
\text { baik berupa program } \\
\text { harian, mingguan, } \\
\text { semester dan tahunan }\end{array}$ \\
\hline & $\begin{array}{c}\text { Pengorganisasi } \\
\text { an }\end{array}$ & $\begin{array}{l}\text { - } \text { Bekerjasama dengan } \\
\text { sekolah dalam penyusunan } \\
\text { kurikulum } \\
\text { - Berkoordinasi dengan guru } \\
\text { mata pelajaran dan guru } \\
\text { pendamping khusus dalam } \\
\text { penyusunan rencana } \\
\text { pembelajaan. }\end{array}$ \\
\hline & Pelaksanaan & $\begin{array}{l}\text { - Berkolaborasi dengan guru } \\
\text { mata pelajaran dan guru } \\
\text { pendamping khusus dalam } \\
\text { Informasi kesadaran } \\
\text { disabilitas } \\
\text { - Menyelenggarakan } \\
\text { layanan informasi } \\
\text { kesadaran disabilitas } \\
\text { kepada orang tua } \\
\text { - Bekolaborasi dengan guru } \\
\text { pendamping khusus dalam } \\
\text { peningkatan ketrampilan } \\
\text { mengajar guru untuk } \\
\text { peserta didik disabilitas } \\
\text { Melaksanakan layana } \\
\text { konseling bagi peserta } \\
\text { didik berkebutuhan khusus }\end{array}$ \\
\hline & Evaluasi & $\begin{array}{l}\text { Menyusun laporan } \\
\text { kegiatan yang telah } \\
\text { dilaksanakan } \\
\text { - Melamberikan } \\
\text { rekomendasi program } \\
\text { dalam penguatan } \\
\text { kesadaran disabilitas } \\
\text { - Melakukan kegiatan } \\
\text { referal (bila perlu) }\end{array}$ \\
\hline
\end{tabular}




\section{PENUTUP \\ Simpulan}

Berdasarkan hasil dan pembahasan dalam artikel kesimpulan penulisan artikel ini adalah pendidikan bagi peserta didik berkebutuhan khusus adalah kewajiban semua bangsa dalam rangka kesamaan hak penyandang disabilitas dalam memeperoleh layanan pendidikan. Pendidikan bagi peserta didik berkebutuhan khusus dapat strategi model segresi, inklusi, dan integrasi. Pendidikan inklusi memiliki beberapa tantangan terutama dalam memenuhi aspek kesadaran disabilitas dan layanan pendidikan yang aksesibel bagi peserta didik berkebutuhan khusus. Kesadaran disabilitas merupakan tugas semua komponen pendidikan termasuk guru bimbingan dan konseling. Dalam upaya menguatkan kesadaran disabilitas konselor dapat melaksanakan strategi layanan bimbingan dan konseling disekolah baik secara langsung berupa layanan klasikal maupun bimbingan kelompok maupun layanan tidak langsung berupa keikut sertaan dalam proses penyusunan program sekolah.

Layanan bimbingan dan konseling yang diberikan merupakan bagian dari rangka menguatkan kesadaran disablitas dapat dilakukan dengan melaksanakan beberapa program bimbingan dan konseling. Fokus implementasi pengembangan dan penguatan kesadaran disabilitas adalah pemahaman mengenai disabilitas semua lingkungan baik fisik maupun non fisik untuk memberikan iklim belajar yang nyaman dan kondusif bagi seluruh peserta didik termasuk peserta didik kebutuhan khusus. Sasaran dari strategi ini adalah seluruh elemen pendidikan, mulai dari kepala sekolah, guru, tenaga sekolah lain, siswa nondisablitas, orang tua, hingga lingkungan sekitar. Melalui program pengatan kesadaran disabilitas konselor telah bertanggungjawab atas kemandirian dan perkembangan seorang peserta didik dengan disabilitas.

\section{DAFTAR PUSTAKA}

Confederation, College. 2017. Disability Awareness: The Basic. E-Book

(Rivonline.org)

Disable People Assosiated. 2012. Achieving Inclution in Education: Understanding the Needs Of Students with Disacilitys. Singapura:-

Permendikbud. 2009. Permendikbud No 70 Tahun 2009 tentang Penyelenggaraan Pendidikan Inklusi. Jakarta: Kementrian Pendidikan dan Kebudayaan

Permendikbud. 2014. Permendikbud No 111 Tahun 2014 tentang Bimbingan Konseling. Jakarta: Kementrian Pendidikan dan Kebudayaan

Rachman, Fathur. 2012. Manajemen dan Pengembangan Program Layanan Bimbingan dan Konseling. Yogyakarta: Modul Pelatihan Guru BK Yogyakarta

Salvia, J, dkk. 2010. Assesment: In Specials and Inclusive Education. Belmont, California: Wadsworth
Schmidt, John J. 2008. Counseling in Schools Comprehensive Programs of Responsive Service for All Student. Boston : Pearson

Ulfatin, N. 2015. Metode Penelitian Kualitatif di Bidang Pendidikan: Teori dan Aplikasinya. Malang: Bayu Media.

Undang-Undang Republik Indonesia. 2003. UndangUndang Republik Indonesia Nomor 20 Tahun 2003 tentang Sistem Pendidikan Nasional.

Undang-Undang Republik Indonesia. 2016. UndangUndang Republik Indonesia Nomor 8 Tahun 2016 tentang Penyandang Disabilitas. 